\title{
Genetic Counselling for Myotonic Dystrophy: A comparison of Lens Examination and DNA Linkage Studies
}

\author{
SIMON LONGSTAFF, DIANA CURTIS ${ }^{1}$, JOHN QUICK $^{2}$, JOHN TALBOT \\ Sheffield
}

\begin{abstract}
Summary
Genetic counselling in presymptomatic individuals with a family history of myotonic dystrophy (DM) is problematic. A genetic test to identify the presymptomatic carrier of the gene for DM would therefore be advantageous. We report studies comparing ophthalmic examination with a genetic test based on DNA linkage studies in nine DM families. The genetic test involved the use of five probes from four loci linked to the DM locus. Some discrepancies between ophthalmic and genetic tests were observed. Genetic counselling following prediction of genetic status was possible for 18 out of 20 patients from seven out of nine families.
\end{abstract}

Myotonic dystrophy (DM) is an autosomal dominant disorder in which the basic gene defect is still unknown. The gene causing DM poses special problems because of the extreme clinical variability of its expression. Many tissues can be affected with variable degrees of severity and the onset of clinical symptoms can occur at any age. Once symptoms have developed, pulmonary and cardiac complications may lead to premature death. The most common ocular abnormalities in patients with DM are lenticular changes, which may be presymptomatic, leading to cataract formation. Varying types of lenticular changes, demonstrated to be present in all symptomatic patients, ${ }^{1,2}$ have been described as iridescent dust like opacities, ${ }^{3}$ small snowball like opacities and posterior subcapsular plaques. ${ }^{1}$ The present consensus view is that exclusion of an individual from gene carrier status may not be possible until after the age of 40 years $^{4}$ on the basis of ophthalmic and neurological examination.

Genetic counselling is a major problem in all DM families because identification of the presymptomatic individuals who carry the gene, which can then be passed on to $50 \%$ of their offspring, is clinically difficult. It is further complicated in heterozygous women since of the $50 \%$ conceptions which will carry the DM gene, $12 \%$ will not come to term, $9 \%$ will result in a child with congenital DM and $29 \%$ will develop symptoms in later life. ${ }^{4}$ In DM families, where age of onset of symptoms is late, decisions relating to childbearing may well have been made before the genetic status of the prospective parent can be determined.

Because of the difficulty in identifying presymptomatic individuals many clinical markers other than examination of the lens have been investigated and evaluated for their ability to predict heterozygous status, including

From: Department of Ophthalmology, Royal Hallamshire Hospital, Sheffield: ${ }^{1}$ Sub-Department of Medical Genetics, University of Sheffield: ${ }^{2}$ Centre for Human Genetics, Sheffield.

Correspondence to: Mr S. Longstaff, FRCSE, FCOphth, Department of Ophthalmology, Royal Hallamshire Hospital, Glossop Road, Sheffield. 
electromyography, ${ }^{5}$ skull X-ray, ${ }^{6}$ serum insulin ${ }^{7}$ and immunoglobulin analysis. ${ }^{8}$ Other workers ${ }^{9,10}$ have identified polymorphic biochemical markers (ABH secretory blood group, the complement component 3 locus (protein C3)) which may be inherited together with the DM gene and which have been assigned to chromosome 19. ${ }^{11}$ Such markers are said to be linked to the DM gene and can be used to track the gene within families. More recently, several polymorphic DNA markers, derived from the gene for apolipoprotein CII (ApoCII), ${ }^{12}$ have been identified which are more closely linked to DM than the protein $\mathrm{C} 3$ linkage group. The development of these polymorphic DNA markers as a genetic test for the presymptomatic carrier of the gene for DM was rapidly reported. ${ }^{13}$ The introduction of further probes helped to solve the problem of the uninformative family and resulted in the genetic test being available for many DM families. ${ }^{14} \mathrm{How}$ ever, problems are encountered with the test because the clinical assignment of the highly variable DM phenotype is still required within each family. Because ophthalmologists are usually involved in the clinical assignment of DM status and thereby in genetic counselling of families with DM, we designed this study to examine the current relationship between ophthalmic assessment and DNA probe studies.

We report both the clinical findings and the results of studies with ApoCII and more recent DNA probes in nine families with well characterised myotonic dystrophy. Prediction of genetic status followed by genetic counselling was possible in seven out of nine families.

\section{Materials and methods}

\section{Clinical and family studies}

Nine families had specifically requested definition of genetic status as soon as DNA tests became available. Family members who were without overt clinical signs of DM were referred for full ophthalmic examination. Fluorescein angiography and electrophysiology were not routinely carried out. Most patients were examined by one observer; four patients were seen elsewhere. In addition all patients had a neuromuscular examination and elec- tromyography was performed in a few cases before clinical status for DM was assigned. Families 2, 3, 4 and 5 all had an original generation with an obligate heterozygote where the disease had not been diagnosed. Family 6 starts with siblings with cataracts.

Within the nine families there are 15 living affected women, with an average age of 39 years. Six of these women have not yet had any children although they are of childbearing age; four have a poor obstetric history, including early pregnancy loss and three dead and one living congenital DM children; five reported no problems in pregnancy. There are 25 affected males in these pedigrees, 12 of whom are dead. Four of the affected males are congenital cases of DM; ten of the men have had families and eleven are childless; of this childless group, six were diagnosed before the age of 20 years and the other five have an average age of 41 years.

The nine families contain 20 enquiring adults. Eighteen of this group have a one in two $a$ priori risk of carrying the gene. Twelve are under 40 years of age, with an average age of 28 years; the other six have an average age of 46 years. These 18 enquiring adults had 19 offspring, 14 of whom were under 18 years of age, dependent on their results. The other two enquiring adults were affected individuals seeking prenatal tests.

Finally amongst the nine families, there are a further seven offspring of four affected individuals with an a priori risk of one in two of carrying the gene; five of these are under 18 years of age, the other two are the adult offspring of a newly diagnosed case.

\section{Laboratory studies}

DNA samples were extracted from peripheral blood lymphocytes from 69 individuals. Table I lists the five probes from four DNA loci linked to DM on chromosome 19 which were used in this study. Between them they identified nine sets of polymorphic markers characterised by the length of the DNA fragment cut by the appropriate restriction enzyme. These markers are known as Restriction Fragment Length Polymorphisms (RFLP). Restriction enzyme digests $3 \mu \mathrm{g}$ DNA per sample were carried out according to the manufacturers instructions, separated on a $1 \%$ agarose gel by 
Table I. DNA probes used in 9 Myotonic Dystrophy families

\begin{tabular}{lccccc}
\hline Probe & DNA locus & Enzyme & RFLP & In service & Source* $^{*}$ \\
\hline Apoc II & APOC2 & Taq I & $3.8 ; 3.5$ & April, 1988 & Humphries (15) \\
& & Ban I & $2.6 ; 1.2$ & April, 1988 & \\
pSC 11 & Nco I & $14.5 ; 11.5$ & March, 1989 & Wallis (16) \\
pJSB 11 & APOC2 & Bgl I & $12: 9$ & May, 1988 & Schepens (17) \\
LDR 152 & D19S16 & Taq I & $8.5 ; 6.5$ & June, 1988 & Bartlett (18) \\
CKM 3' & D19S19 & Msp I & $2.3 ; 1.3$ & January, 1989 & Perryman (19) \\
& CKMM & Taq I & $4.5 ; 3.8$ & March, 1989 & \\
\hline
\end{tabular}

*We are grateful to these workers for their gift of probes.

electrophoresis and blotted onto Hybond-N filters. The probes were oligolabelled and hybridisation carried out for more than 16 hours at $65^{\circ} \mathrm{C}$ in the presence of $10 \%$ dextran sulphate. The filters were washed free of non specifically bound probe and an autoradiograph of the filter was made showing the polymorphic marker data.

\section{Results}

\section{Linkage studies}

Polymorphic markers from 69 individuals in nine families were analysed. The original work with the ApoCII probe demonstrated both the highly polymorphic nature of the Taq I RFLP and strong linkage disequilibrium ${ }^{20}$ between the markers of the ApoCII and the pSC 11 probes. Because of this, only three of the nine families were fully informative. The final results obtained with the full battery of probes resulted in seven fully informative families. Figure 1 shows the results of RFLP analysis in family 6 , from which the markers which are tracking with the DM gene can be identified. We observed one recombinant event which was between ApoCII and CKM $3^{\prime}$ in family 1 .

\section{Analysis of pedigrees}

Table II shows the nine families compared across the generations. In generation I, the probes identified the putative obligate heterozygote in families 2, 3, 4 and 5. In generations II and III the numbers of affected individuals together with their mean age is given; the enquiring adults are identified within their generation. All families show a reduction in the mean age of diagnosis with successive generations.

\section{Analysis of Individual results}

Table III lists the results which were given to the 20 enquiring adults after both clinical and DNA tests were complete. The two clinically affected patients had well established DM and the probe results enabled the counsellors to offer them prenatal diagnosis. The 18 enquiring adults were all clinically normal following neurological examination including those where electromyography was carried out. Seventeen of the group had corrected acuity of $6 / 6$ or better and were without lenticular abnormalities. Fundal examination revealed no peripheral or macular pigmentary changes. Thus ophthalmic and neurological examination failed to identify any further carriers of the DM gene. In contrast, the DNA results showed that two males of this group had probe markers suggesting they carried the DM gene; results which are in conflict with the clinical findings. One 45 year old enquiring adult had equivocal lens opacities, thought to be atypical of DM and her probe markers were normal.

\section{Discussion}

The extremely variable expression of the DM gene is well demonstrated by the range of recorded ophthalmic pathology. Ptosis, oculomotility abnormalities, epiphora, corneal changes, ocular hypotony, ${ }^{1}$ macular and peripheral retinal pigmentary changes ${ }^{21}$ have all been described in DM individuals. Lens opacities which may develop into visually significant cataracts are the most significant ophthalmic finding, all patients with DM being affected ${ }^{1,2}$ Lens changes are small discrete iridescent crystals, ${ }^{3}$ though small white opacities and posterior subcapsular changes 
Fig. 1 Pedigree for family 6 showing DNA test results

II
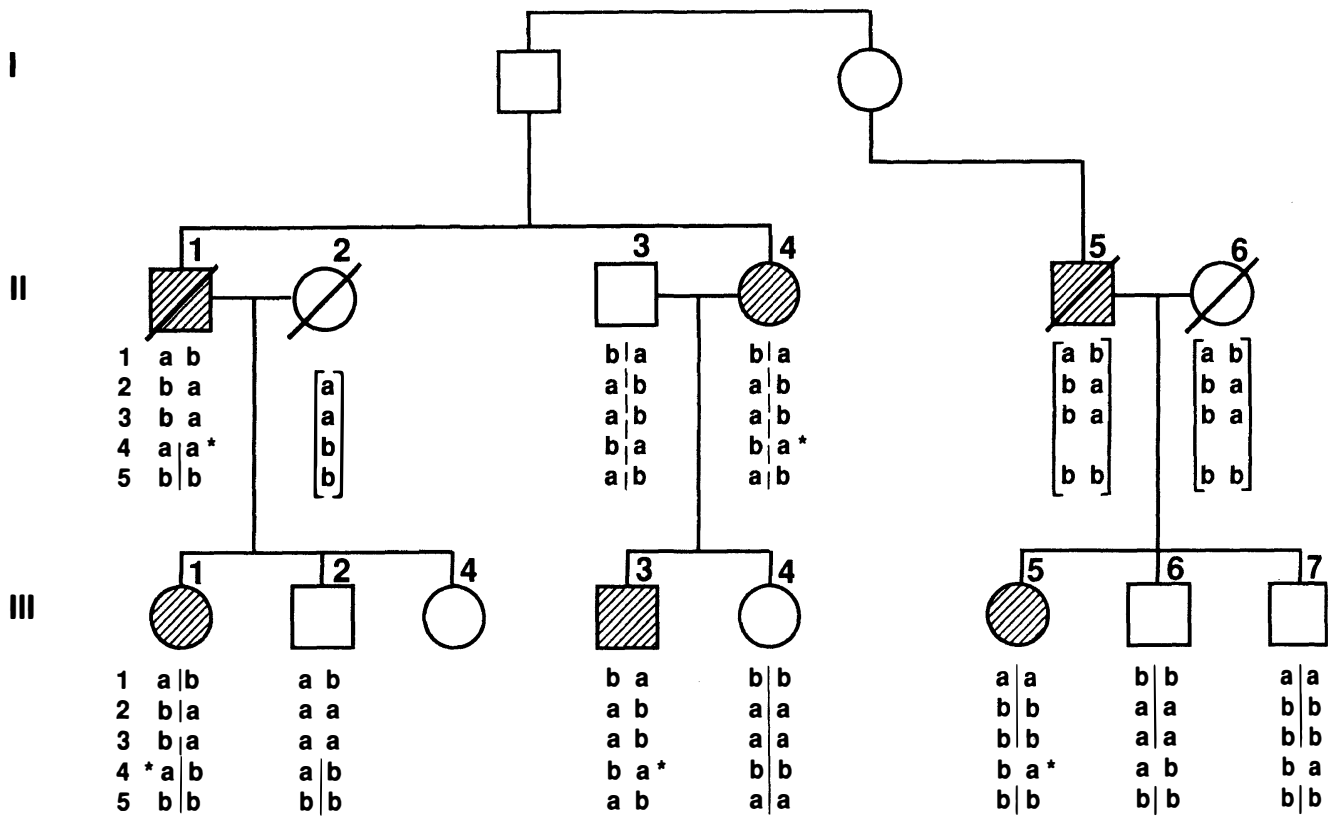

Haplotypes in brackets are derived.

Haplotype on left inherited from male parent. Haplotypes separated by I, are phase known;

Haplotype separated by $\nmid$ are phase derived.

* identifies the best informative marker in this family.

Fig. 1 .

have been described. ${ }^{1}$ Slit lamp biomicroscopy of the lens for early characteristic opacities is routinely undertaken as a marker of carrier status in the presymptomatic patient. Because lens opacities occur presymptomatically, ${ }^{5,22}$ patients are frequently referred for ophthalmic assessment during genetic coun- selling, in conjunction with neurological examination. Originally Harper ${ }^{22}$ suggested that slit lamp examination would identify all presymptomatic carriers before the age of twenty. However, Bundey ${ }^{23}$ suggested that the age of presymptomatic detection of early lens opacities was related to the age of symp-

Table II. Analysis of Pedigrees

\begin{tabular}{|c|c|c|c|c|c|c|c|c|c|}
\hline Family & 1 & 2 & 3 & 4 & 5 & 6 & 7 & 8 & 9 \\
\hline \multirow[t]{2}{*}{ I } & D & ND & ND & ND & ND & ND & D & D & D \\
\hline & & 60 & 80 & 80 & 60 & NK & & & 40 \\
\hline \multirow[t]{2}{*}{ II } & $50(1)$ & $34(2)$ & $37(3)$ & $53(2)$ & $21(3)$ & NK(3) & $10(1)$ & $42(3)$ & $19(3)$ \\
\hline & & $1^{*}$ & $1^{*}$ & & $2 \mathrm{PN}$ & & $3^{*}$ & & $1^{*}$ \\
\hline \multirow[t]{2}{*}{ III } & $26(1)$ & & $15(2)$ & $22(4)$ & & $41(3)$ & & $20(1)$ & \\
\hline & $1^{*}$ & & $3^{*}$ & $3^{*}$ & & $4^{*}$ & & $1^{*}$ & \\
\hline
\end{tabular}

D: diagnosed; ND: not diagnosed; NK: not known; PN: prenatal diagnosis

Figures given as mean age of affected patients with number of affected patients in brackets Enquiring adults indicated by an asterisk 
Table III. Results of clinical examination and probe studies

\begin{tabular}{lccc}
\hline Nos & Age & Clinical Status & DNA test \\
\hline 4 & $>40$ years & unaffected & normal marker \\
9 & $<40$ years & unaffected & normal marker \\
1 & 45 years & equivocal & normal marker \\
1 & 20 years & unaffected & DM marker \\
1 & 43 years & unaffected & DM marker \\
2 & - & affected & PN \\
2 & & unaffected & uninformative \\
\hline
\end{tabular}

tomatic DM in any particular pedigree. The present consensus is that exclusion of the individual from gene carrier status may not be possible until after the age of 40 years. $^{4}$

Because of the difficulty of identifying the presymptomatic carrier of the DM gene, the prospect of a more sensitive test utilising DNA linkage studies was appealing. However, this type of linkage study is only useful if the DNA marker is close to the disease gene, because crossing over (recombination) occurs between the chromosomes at meiosis at a rate dependant on the distance between the marker and the gene. The effect of recombination is to introduce an error into the linkage analysis whereby the disease gene is no longer tracking with the original marker.

These studies were initiated in order to give genetic counselling to 20 enquiring adults from nine families. With one exception, the families were known to us before the DNA tests were undertaken and the prospect of such tests becoming available had been discussed with the families over the last two to three years. The initial screening of nine families known to our Clinical Genetics Service with the ApoCII -probe was disappointing. The DNA markers were highly polymorphic making it difficult to track the gene within the family and the markers themselves tended to track together (linkage disequilibrium). Since we could not resolve carrier status using the DNA probes we still had to rely on clinical examination in six families. The introduction of newer probes resolved this problem.

Of our group of 20 enquiring adults, two were clinically affected women who were planning to have a prenatal diagnosis as a result of the DNA tests; neither has yet made such a request. Thirteen patients were clinically unaffected and informative DNA tests indi- cated that they did not carry the DNA marker tracking with the DM gene in their family. They were therefore given a low probability of between $2-5 \%$, dependent on the particular informative marker, of carrying the gene for DM. These 13 individuals had DNA test results which were congruent with their clinical status. The remaining five patients were more difficult to resolve. The DNA test results in two of this group were uninformative. Both were clinically unaffected with an a priori risk of $50 \%$ of carrying the DM gene. This risk could not be modified following tests and examination. One 43 year old woman had equivocal lens opacities not thought to be characteristic of DM. Her DNA test results showed the unaffected marker and she was given a low risk of carrying the DM gene. The final two patients were clinically unaffected, but informative DNA tests indicated that they carried the DNA marker tracking with the gene in their particular family. Both therefore have a high probability $(95-98 \%)$ of carrying the gene for DM. One of these patients was 20 years of age and therefore the risk of becoming clinically affected within the next five years remains high. The other patient is in his early 40s and is without signs of the disease. He could therefore be a recombinant for the gene markers. If all the information, including his unaffected clinical status and his age is taken into consideration, his risk of carrying the gene for DM, using the MLINK section of the computer programme LINKAGE, has been calculated at 0.82 (approximately $80 \%$ ). Thus his final risk of carrying the gene for DM, although reduced from $98 \%$ to $80 \%$, remains high.

These individual results indicate the difficulties encountered in providing presymptomatic tests in DM families. The first problem is to interpret the lens examination with reference to the age of the patient. Table II which summarises some of the family data, clearly demonstrates the simple assertion that the age of affected individuals decreases through the generations. This controversial phenomenon, which had been referred to as anticipation, was formerly ascribed to a statistical artefact of biased data gathering. ${ }^{24}$ Recent work ${ }^{25}$ strongly suggests that anticipation may be inherent in the transmission of the disease, which has important practical consequences for genetic counselling. It would therefore appear that the 
lens examination needs to be referred to the age of the patient and to the particular family under study, with the advice of Harper ${ }^{4}$ forming a general guideline. This present study demonstrates some of the limitations of lens examination in the presymptomatic detection of DM. However the study also highlights the continuing necessity for good ophthalmic examination together with neurological assessment in all DM families and is particularly important in families where DNA tests are uninformative.

DNA tests should give a much more accurate assessment of the presymptomatic status of the individual. They also have their own error due to recombination and, since the markers must be assigned in each family, they remain firmly based on the clinical definition of an affected phenotype. The problem of recombination will be much reduced when probe markers which flank the gene are available. The problem will only be fully resolved when the gene for DM can be located and the abnormal sequence described.

Key words: DNA probes; Myotonic Dystrophy; Genetic Counselling; Lens abnormalities

\section{References}

${ }^{1}$ Burian HM and Burns CA: Ocular changes in Myotonic Dystrophy. Am J Ophthalmol 1967, 63: 22-34.

${ }^{2}$ Raitta C and Karli P: Ocular findings in Myotonic Dystrophy. Ann Ophthalmol 1982, 14: 647-50.

${ }^{3}$ Duke-Elder S: System of Ophthalmology. London. Kimpton. 1969, 11: 186-187.

${ }^{4}$ Harper PS: Myotonic dystrophy. Philadelphia. WB Saunders. 1979.

${ }^{5}$ Bundey S, Carter CO, Soothill JF: Early recognition of Heterozygotes for the Gene for Dystrophia Myotonica. J Neurol Neurosurg Psychiat 1970, 33: $271-93$.

${ }^{6}$ Walton JN and Warwick CK: Osseous changes in Myopathy. Br J Radiol 1954, 27: 1-15.

${ }^{7}$ Karpati G: Abnormal insulin homeostasis in Myotonic Dystrophy Trends. Neurosci 1985, 8: 141-3.

${ }^{8}$ Wochner RD et al: Accelerated breakdown of Immunoglobulin $\mathrm{G}(\mathrm{IgC})$ in Myotonic Dystrophy: A Hereditary error of human catabolism. J Clin Invest 1966, 45: 321-29.

${ }^{9}$ Renwick JH, Bundey SE, Ferguson-Smith MA, Izatt MM: Confirmation of linkage of the loci for myotonic dystrophy and $\mathrm{ABH}$ secretion. $\mathrm{J} \mathrm{Med}$ Genet 1971, 8: 407-16.

${ }^{10}$ Whitehead AS, Solomon E, Chambers S, Bodmer WF, Povey S, Fey G: Assignment of the structural gene for the third component of human complement to chromosome 19. Proc Natl Acad Sci USA 1982, 79: 5021-6.
${ }^{11}$ Davies KE, Jackson J, Williamson R, Harper PS, Ball S, Sarfarazi M, Meredith L, Fey G: Linkage analysis of myotonic dystrophy and sequences on chromosome 19 using a cloned complement 3 gene probe. J Med Genet 1983, 20: 259-63.

${ }^{12}$ Shaw DJ, Meredith AL, Sarfarazi M, Huson SM, Brook JD, Myklebost O, Harper PS: The Apolipoprotein CII gene: subchromosomal localisation and linkage to the myotonic dystrophy locus. Hum Genet 1985, 70: 271-3.

${ }^{13}$ Meredith AL, Huson SM, Lunt PW, Sarfarazi H, Harley HG, Brook JD, Shaw DJ, Harper PS: Application of a closely limited polymorphism of restriction fragment length to counselling and prenatal testing in families with myotonic dystrophy. Br Med J 1986, 293: 1353-6.

${ }^{14}$ Norman AM, Floyd JL, Meredith AL, Harper PS: Presymptomatic detection and prenatal diagnosis for myotonic dystrophy by means of linked DNA markers. J Med Gen 1989 26: 750-4.

${ }^{15}$ Humphries SE, Jowett NI, Williams LG, Rees A, Vella MA Kessling A, Mykelbost O, Seed M, Galton DJ, Williamson R: A DNA polymorphism adjacent to the human apolopoprotein CII gene. Mol Biol Med 1983, 1: 463-71.

${ }^{16}$ Wallis SC, Donald AJ, Forrest LA, Williamson R, Humphries SE: The isolation of a genomic clone containing the apolipoprotein CII gene and the detection of linkage disequilibrium between 2 common DNA polymorphisms around the gene. Human Genet, 1984, 68: 286-9.

${ }^{17}$ Schepens J, Smeets H, Hulsebos T, Brunner H, Wieringa $\mathrm{B}$ : Isolation of a polymorphic DNA sequence pJSBII (D19S16) from the human chromosome 19 cen -q13.2 region linked to the myotonic dystrophy (DM) gene. Nucleic Acids Res 1987, 15: 3192.

${ }^{18}$ Bartlett R, Pericak-Vance M, Yamaoka L, Gilbert J, Herbstreith M, Hung W-Y, Lee J, Mohandas T, Bruns G, Laberge C, Thibault M-C, Ross D, Roses A: A new probe for the diagnosis of myotonic muscular dystrophy. Science 1987, 235: 1648-50.

${ }^{19}$ Perryman MB, Hejmancik JF, Ashizawa T, Armstrong R, Linn S-C, Roberts R, Epstein HF: Ncol and TaqI RFLPs for human $\mathbf{M}$ creatine kinase (CKM). Nucleic Acids Res 1988, 16: 8744.

${ }^{20}$ Appleby VL, Coleman, RT, Frossand PM: Linkage disequilibrium at the human apolipoprotein CII gene locus. Am J Hum Genet 1986, 39: A145.

${ }^{21}$ Hayasaka S, Kiyosawa M, Katsumata S, Handa M, Takase S, Mizano K: Ciliary and Retinal Changes in Myotonic Dystrophy. Arch Ophthalmol 1984, 102: 88-93.

${ }^{22}$ Harper PS: Pre-symptomatic Detection and Genetic Counselling in Myotonic Dystrophy. Clin Gen 1973, 4: 134-40.

${ }^{23}$ Bundey S: Detection of Heterozygotes for Myotonic Dystrophy. Clin Gen 1974, 5: 107-9.

${ }^{24}$ Penrose LS: The problem of anticipation in pedigrees of dystrophia myotonica Ann Eugenics 1948, 14: 125-32.

${ }^{25}$ Howeler CJ, Busch HFM, Geraedts JPM, Niermeijer MF, Staal A: Anticipation in myotonic dystrophy: fact or fiction? Brain 1989, 112: 779-97. 